\title{
Subaltern Perspective of the British Empire in Kipling's Kim
}

\section{Bimal Kishore Shrivastwa}

Assistant Professor (English), P.G. Campus (T.U.), Biratnagar, Nepal

\begin{abstract}
The present article explores the subaltern ideology of the British Empire in India in Kipling's novel, Kim. Kipling's view of Indian people's habit, language and the different ways of living the life shows that Indians can be out witted and dominated by the British. In the novel Kim, Kipling has mentioned that Indians lack sense of time and do believe in their ability to tell a lie. It is somewhat drowned in Orientalist ideals and British colonialism. Kipling seems to be a little bigoted towards the Empire. The article seeks to demonstrate a gap between the natives and the European officials. Kipling as a colonialist admires the work of the civil servants who bring European inventions and the so called progress to this part of the world which he considers inferior to the West. But at the same time he points out the mistakes they make. This research paper elaborates the research hypothesis that the British treat Indians as inferior and assume themselves as the rulers. It explores the real intentions of the west to dominate east in the great game of the principle of domination.
\end{abstract}

Keywords-Colonialism, Hegemony, Imperialism, Occidental, Oriental.

\section{INTRODUCTION}

Post-colonial literature depicts the contrast between the oriental and the occident. The hegemonic power structure just wants to justify the inferior other's point of view to defend the notion of subalterns. According to Said, "Kim is a post colonial text and such texts are highly biased which depict the orient people irrational" (1994: 67). In this context Kipling's view of Indian people's lifestyle, language and the ideology and action shows that Indians can be made submissive and dominated by the British. Hopkirk (1996) judges that "Much has been written on Kipling's racism, and no doubt there are racist elements in Kim (43)". Joseph Rudyard Kipling (1865-1936) was a journalist, short-story writer, and novelist and was awarded Nobel Prize for Literature in 1907. Kipling's works of fiction include The Jungle Book(1894), Kim (1901), and many short stories, including The Man Who Would Be King (1888).

In the novel Kim, Kipling has mentioned that Indians lack judgment of time and do believe in their ability to tell a lie. Kim is a story of a quest under taken by Kimball O' Hara the son of an Irish soldier, now an orphaned street urchin who lives in Lahore. Kipling is sensitive to nuances of Indian speech and the life lived here enables him to find the smell of inferiority. In this novel Kipling presents the superiority of the active life of occident over the lazy way of life lived by oriental. Lama, a follower of middle way seeks a river that will wash away sins and Kim is looking for "Red bull on green field (18)". It means the Red British army marches on the green Indian fields to dominate the Indian soil. On the other hand, Kim is a predominantly male-oriented novel with women as distant presence put into the sphere of the man's world. The novel has a layered structured in which we find the perspective of the imperialist ideology. Kipling shows his sense of belonging in Kim but not without contradictions .Kipling as journalist tried to differentiate between the life he lived with his parents and the life working for the British interests. Kipling considers imperial rule as a philosophy that celebrates the superiority of British culture and civilization. He seems to be the spokesperson of the empire and tries to justify the cruelties of the British rule on the Indians under the pretext of law and enlightenment. Kim is a pro-imperialist novel which mentions the authority and benevolence of imperial rule in India. This novel further presents the western attitude towards Indian people through the biased portrayal of Indian characters in the novel. Kipling has idealized imperial British rule in India by showing the developmental works undertaken by British government. In this way he celebrates the energy and vitality of the imperial 
rule, power and brings forth the meekness of Indians. Kipling has made many other biased and rash generalizations about India and its people in this novel. It means we can't defend or excuse Kipling's attitude but it can be discussed as a historical fact which has its unique place in the history of India and in the history of English literature.

\section{RESEARCH PROBLEMS}

The research seeks to analyze and answer these questions: Why does a young Irish boy, Kimball O'Hara, Kim make adventures in the British colonial India? Why does he volunteer an elderly Tibetan Lama and become his disciple in order to go adventuring on the monk's pilgrimage? Are the British really liberal to the Indians?

\section{Research Objectives}

The objective of this research is to highlight how Kim is set in an imperialistic world, a world strikingly masculine, dominated by travel, trade and adventure, however, a world in which there is the division between white and non-white, hegemony and subalterns. It also aims at showing the difference of the treatment between the hegemonic group and the subalterns.

\section{Working Hypothesis}

Kim pictures how the colonizers have dominated and exploited the orient, subaltern people in the name of educating, civilizing and even humanizing them presenting themselves as the rational, strong, and masculine while assuming the colonized as subalterns, irrational, strange, week and even feminine .

\section{RESEARCH METHODOLOGY}

The methodology of this research is textual as constructed and guarded by circumference of postcolonial and subaltern approach. Apart from the intensive study of the text, the methodological tools are also drawn from different theories, if needed especially about the condition of the people in the colonized society. For the collection of the related materials, articling the library, websites, and magazines will be taken as secondary sources to justify the hypothesis.

\section{Analysis and Interpretation}

Kim (1901) is Kipling's last novel in which he presents the story of an Irish boy who grows up independently in India. Kim grows up as a native and knows how to communicate with the large groups of people in India. When he meets
Lama, they make a journey around India. After this journey Kim gets the knowledge Indian culture and habits of the people. He also visits the army regiment where his father has worked. So, Kim is the blend of double identity that is represented as the guide for British Empire. It is true that both India and British Empire cause the problem of identification for the colonial subjects. Here Kim from an Irish family is able to have an appropriate relationship with the natives by adapting elements of Indian culture and integrating himself into the Indian community. In this regard, Bhabha rightly observes that "Kim is an in between character whose interstitial position is needed to empower the desire of imperialism and this estranges any immediate access to an ordinary identity (1994: 2)". Kim is presented as a person who has acquired all the customs of the country which he knew and loved.

In the novel Kim, Kipling compares Kim and Hurree Babu from different perspectives. Kim faces the problem of double identity. One way he realizes that he is a British and on the other he sometimes finds himself as an Indian. This type of feeling is the result of strange mixture of prejudices against the natives because European considered Indian and their culture an inferior to the European. In his important work Orientalism (1978). Said (1994) says that "Orientalism is a style of thought based upon an ontological and epistemological distinction made between the Orient and the Occident (14)." Kipling's observations regarding the Indian customs and society show that he is a classified colonialist. In the novel he admires the work of the ordinary civil servants, engineers, architects and other agents of the British Empire. In this regard Carrington (1955) says:

If India was being wickedly exploited, certainly they (the English Officials) were not the exploiters. It could not be denied, by anyone who took the trouble to enquire, that they were giving India internal security, communications, precautions against famine, irrigation, afforestation, even the rudiment of an educational system, on a scale that no other country in continental Asia or Africa could approach. These young Englishmen had much to be proud of, and it was a matter of pride with Kipling to serve for seven years in this unselfish army. (83)

It happened because at that time in Europe nationalism was a powerful issue which is reflected in the novel by Kipling. 
Now we will take some of the examples from the novel which support this point of view. Kipling depicted India as a country where the Europeans are confronted with different castes and religions and find they confused. Kipling narrates the story where Kim is caught by two white British priests within a military unit. But here Kim writes to his friend Mahbub Ali to rescue him from that situation. As it is not a difficult task for Mahbub Ali, nobody knows him and when he puts Kim on his horse and rides away then nobody knows where to search them as it was difficult for them to search in the native surroundings. Kipling therefore presents a kind of knowledge as well as social relationship of Kim through his friendship and relationship with the natives which he finds important value in Indians. This is the result of the being brought up in Indian society by a half caste woman. Kim's close friends are all Indians and his knowledge of native India is deep. However, he is completely bewildered by the world of the Europeans. Therefore, it signifies that he is culturally separated from them and belongs to the Indian world. Kim refers to the priests as to the „thin foole ${ }^{\text {,e }}$ fat- fool and ,the camel like fool"e. At the beginning of his captivity among the British soldiers, he claims that it is an interesting experience to be a sahib and having found himself as a European. Now he believes that it is an amusing cultural change. Before this he was a chela and now he is a sahib. Kim thinks in Hindi language and finds very difficult to translate them into English language. It is because Kim is not well acquainted with the English speaking and celebrated authors in England like Shakespeare who has been regarded as inevitable for the British. The only tie to the European for Kim is his biological descendancy. But here, Kipling shows that his European parents died when he was just three years old. It means Kipling gives more importance to the descendancy and ethnicity at the expense of other values of environment in which he has grown up.

Another character which is just different from Kim is Hurree who is of Oriental origin. But he is pro-European and proBritish. Being a spy he risks his life for the British. Moreover, he is also very much interested in the official British culture and has classical education of the Europeans. Kipling has different approach for these two characters in the novel. Kipling treats Hurre as an Oriental although he has a British taste. As he says "I am unfortunately Asiatic, which is serious detriment in some respects. And all-so I am Bengali-a fearful man (297)." He is not a negative character but also shows his virtue when he listens to Lama reverentially, he is presented in such a way that he shows his true nature:
He [ Hurree ] himself had been taught by sahibs, who do not consider expense, in The lordly halls of Calcutta; But as he was first to acknowledge, they lay a wisdom behind Earthly wisdom -the high and lonely lore of meditation. Kim looked on with envy. The Hurree Babu of his knowledge -oily, effusive, and nervous was gone, gone too, was the brazen drug vendor of overnight. (301).

In the above mentioned quote, Kipling presents a change of character that seems to exist in two forms. The first one is Hurree who is "oily, nervous and effusive" and he finds some respect when he advances to Lama is the second one. This is just contradictory because of his classical British education, for example his use of Latin words and when he speaks about Shakespeare. Now it is quite interesting that in some way he is connected with European environment and still he targeted as an Oriental. Hurree Babu also expresses his positive attitude towards the oriental culture as expressed; he is perceived positively but his inclinations towards western values are always depicted as pictures but seem rather funny and opportune. Here Kipling chooses everything by ethnicity rather than the freedom of the characters in the novel. In this regard Williams (1994) says "In Kipling's writings the Indians are superior to the British in the matter of religion as the British are to them in material" (483).

Hurree is of Oriental origin and his approaches are portrayed as to the European culture which is quite ridiculous and funny where as his mentality is presented as completely Oriental. It means Kipling does not approve mixing of races. Therefore, Kipling designs his characters by ethnicity and not by the cultural aspirations. Colonial superiority shapes the character and identity of Kim and in the process of learning Kim forms a new image of Brutishness. This involves some connection with British culture, English Language and even the role of church. But Kipling puts Kim in the main frame of his descendancy from parents and ethnicity which gives his Brutishness a specific taste. Here, we find that Kim express his ideas like this, "Kimball, I suppose you would like to be a soldier. Gorah- $\log$ [white folks]. No-ah, No-ah. Kim shook his head violently. There was nothing in his composition to which drill and routine appealed. I will not be a soldier (127)". The British ruled India by having the post of soldiers, civil servants and rulers and they were considered by the natives in the same role. In the character of Kim, the consciousness of belonging to Britain exists to keep his 
Indian culture away. So, the character of Kim is blended with two types of components. First Kipling's praise for Indian culture and his partial identification with it and the other one is his thinking that British are the suitable rulers of the natives.

Kim is a novel in which Kipling shows his fondness of the native culture. But at the same time he also draws the boundaries between his own position as the ruler and the admiration of Indian culture. The character of lama is displayed with Kipling's this kind of thinking. $\mathrm{He}$ is an enjoyable figure in the novel. He shows his love for the living creatures and children which means he is having the humanity that reduces the distance between the Oriental and the European. But Kipling stress on the benefits of the colonial rule in the less civilized Oriental countries. Lama accepts this kind of Kipling's approach towards the natives. Even though Lama is positively portrayed but he bears the colours of the British. In fact producing the in- between sense of belongingness in half educated natives is to just assist the political domination of British rulers. Although colonial discourse desires reformation and regulation of the colonized Indians, it does not consider these natives equal to their own level in any sense. In this regard Said states that "Kim is a person capable of changing his appearance quickly like chameleon-like character" (1994: 155). In the novel Kim, Kipling gives emphasis on the instability of Kim's identity. Kim is a double agent who is an Irish orphan and also acts like the native.

In this novel Kipling described the world of native in contemporary India. He also relates it to the world of colonizers. Kipling presents the images of Indian city which supports the idea of distance between the civil servants and the native community. He also describes "Smile as a conglomeration of verandas, alley -ways and bolt -holes, and the city where the police controlling the inhabitant's familiar with the place encounter serious difficulties (68)".

In this novel the reader can notice a gap between the natives and the European officials. Kipling as a colonialist admires the work of the civil servants who bring European inventions and the so called progress to this part of the world which he considers inferior to the West. But at the same time he points out the mistakes they make. In this regard Carrington remarks, " the Native -Born [is] an appeal from the colonial born overseas for a little understanding on the part of his English brother (259)". This kind of attitude is found in the character of Kim.

\section{CONCLUSION}

Thus in Kim, Kipling is detailed in his account of a colorful, diverse and complicated India and Indian culture, albeit, views them through a colonist's lens. It's quite odd to note Kipling's use of humor in Kim to underscore his characters' awareness of themselves, of their suffering, and of the imbalance, unease, and ambivalence of their social and political environs. Kipling presents India as mixture of the old customs and traditional life style of the native castes with the modern inventions and the progress of the British -Raj. But the two parts of the life did not mix with each other and remain far away from the blending of it. Kim tries to define the bond between the two worlds of colonizers and the native Indians but he did not succeed completely in his motive because Kim is also a victim of the rulers' arrogance to the natives. The novel therefore does not offer a scrutiny of the native people of India of that particular period of the colonial rule, but it is rather a picture created by the colonizers. Kipling offers a vision of Indian society and culture admired by the British. He admired the efforts of ordinary people just to survive and not to achieve anything in the world. Kim is a descriptive novel centered on the differently flavored atmosphere of India presented through a variety of characters. The relationship between the British and the native population is an indispensable part of India as represented in the novel, reveals the great distance between their world and cultures. We can feel after reading the novel that the outcome of the colonialism still exists in different forms, that is, corruption, wars, bloodshed, coups and chaos in many of the ex-colonies of the then empire. This kind of approach has been used to justify the occupations and horrors that accompany the oriental world.

\section{REFERENCES}

[1] Bhava, Homi K. (1994).The Location of Culture. London: Routledge.

[2] Carrington, Charles (1955). Rudyard Kipling: His Life and Work. London: Macmillan.

[3] Hopkirk, Peter (1996). In Quest for Kim. London: J. Murrey.

[4] Kipling, Rudyard (1994) Kim, London: Macmillan.

[5] Said, Edward (1994). Orientalism. London: Vintage.

[6] Williams, Patrick (1994) "Kim and Orientalism". Colonial Discourse and Postcolonial Theory: A Reader. Ed. Patrick Williams. Cambridge: Cambridge UP. 